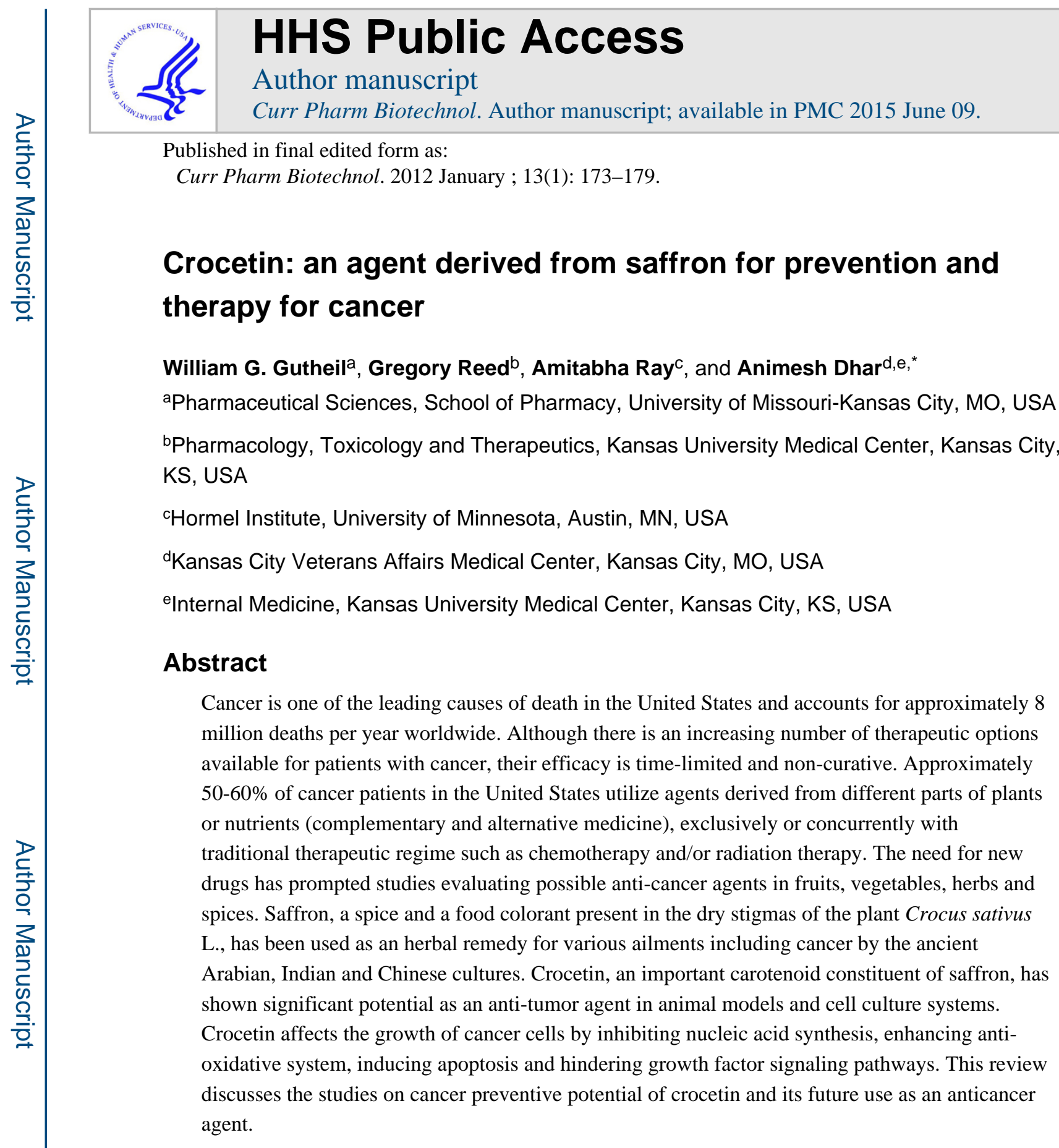

Keywords

Cancer; carotenoids; chemoprevention; crocetin; saffron

\title{
INTRODUCTION
}

Cancer continues to represent the largest cause of mortality in the world claiming more than 8 million people each year [1]. A total of approximately 1,530,000 new cancer cases and

*Address correspondence to this author at the Kansas City Veterans Affairs Medical Center, 4801 Linwood Boulevard, Kansas City, MO 64128, USA; Tel: + 8168614700 extension 57103; Fax: +816 922 4712; adhar@kumc.edu. 
about 570,000 deaths from cancer are projected to occur in the United States in 2010 [1].

Currently chemoprevention is very attractive aspect and has demonstrated serious consideration for cancer management. Considerable interests have been developed on the role of plant products and spices to diminish tumor development. An important element of chemopreventive drug development using plants is the accumulation and analysis of pertinent experimental data and folklore uses of plants. It is also important to note that suitable chemopreventive natural agents should have no or negligible toxicity, a high efficacy, to be orally administrable, and with a known mechanism of action and low cost [2]. Several of the isolated compounds like flavone, carotenoids, isothiocyanates, polyphenols coumarins, a-angelica, gingerols, curcumin and other polyphenols from different plants such as, soy, broccoli, green tea, turmeric, tomato, saffron, garlic and black cumin have been reported to inhibit the growth and progression of chemically induced tumors [3-5].

Natural carotenoids are highly pigmented compounds that consist of eight isoprenoid units found either as hydrocarbons or as oxygenated compounds [5, 6]. A growing body of evidence indicates that carotenoids possess anti-carcinogenic, anti-mutagenic and immunomodulating effects [7, 8]. Retinoids (vitamin A and its derivatives) and carotenoids have been shown to inhibit the growth of certain types of tumor cells, including leukemia, neuroblastoma, breast and colon adenocarcinoma. Moreover, retinoids and carotenoids and their synthetic analogs were proposed for experimental chemoprevention and even for treatment of cancer [8-12]. Nevertheless, their toxicity remains an important limiting factor for using the class of compounds at high therapeutic doses [9-21]. It is known that dietary factors play an important role in both cancer proliferation and prevention. Epidemiological studies demonstrated that there are reports regarding the inverse relationship between the ingestion of carotenoid-containing fruits and risk of certain cancer [22-25].

There are many compounds from natural products that demonstrated tumor-suppressing activity, thus being potentially useful in the treatment of cancer. Extracts of some spices were found to inhibit the growth of transplanted tumors in mice as well as being cytotoxic to cells in tissue culture [5, 25, 26]. Saffron, a spice and food colorant present in the dry stigmas of the plant Crocus sativus L., was used to treat various diseases, particularly cancer, by Arabian, Indian and Chinese people in ancient times. Saffron possesses a rich source of carotenoids in addition to riboflavin [27, 28]. Crocetin, an important commercially available constituent of saffron, showed significant potential as an anti-tumor agent in animal models and cell culture systems [29-32]. The principal active substances present in saffron are picrocrocein, safranal, crocin and aglycon crocetin. Safranal is a cyclical terpenic aldehyde and picrocrocin is a glycoside combining with glucose and an aglycon, 4-hydroxy$\beta$-cycloctral [33]. Crocin is a crocetin digentiobiase ester whereas crocetin (the aglycon of crocin) is $88^{\prime}$ diapo- $8,8^{\prime}$-carotenoic acid [33]. Crocetin is a diterpenic compound has been demonstrated as the most potent carotenoid in saffron [33], therefore, the present review will provide the role of crocetin derived from saffron in chemoprevention and its ability for modifying cancer risks. 


\section{CHEMISTRY OF CROCETIN}

Crocetin belongs to the large family of natural dyes known as carotenoids, but it does not have a pro-vitamin function [33]. The constituents of this class of small molecule compounds are mostly polyunsaturated hydrocarbons (the formula is $\mathrm{C}_{40} \mathrm{H}_{56}$ ) or their oxygenated derivatives. There are small groups of caretonoids that are carboxylic acids. Among those groups there is crocetin (the glycan of crocetin), 8,8'diapo- $8,8^{\prime}$-carotenic acid, characterized by a diterpenic and symmetrical structure with alternating double bonds and four methyl groups. The chain is stabilized in the terminal parts by two carboxylic groups. Its elementary composition is $\mathrm{C}_{20} \mathrm{H}_{24} \mathrm{O}_{4}$ and its molecular weight is 328.4 . It is slightly soluble in aqueous solution ( $20 \mu \mathrm{M}$ at $\mathrm{pH} 8.0)$ and it is soluble in organic bases, such as, pyridine. Various analytical methods have been developed including thin-layer chromatography [8,33-37]. Chemical analyses of dry stigma of saffron extracts have revealed that characteristic compounds of saffron include the carotenoids, namely crocin and crocetin and the monoterpene aldehydes picocrocin and safranal [35-37]. Crocetin is an amphiphilic low molecular weight carotenoid compound and consists of a C-20 carbon chain with multiple double bonds, and a carboxylic acid group at each end of the molecule. The structure of crocetin is presented in Fig. (1), where R1 and R2 = H.

\section{PHARMACOLOGICAL PROPERTIES OF CROCETIN}

Animal studies indicated that the oral $\mathrm{LD}_{50}$ of crocetin or saffron was $20.7 \mathrm{~g} / \mathrm{kg}$ body weight when administered as decoction [38]. It has been demonstrated that oral administration of saffron extract at doses from 0.1 to $5 \mathrm{~g} / \mathrm{kg}$ was non-toxic in mice (38). The stability of crocetin is also dependent upon temperature, light and humidity on degradation of potency under storage conditions. Ingredients of saffron including crocetin can be stored under $-20^{\circ} \mathrm{C}$. Its pharmacological activity remains unaltered for at least 2 years [38].

Saffron and its constituents have been demonstrated significant medical-biological activities as described by Abdullaev and Espinosa-Aguirre [30]. It has been reported that saffron derived compounds like crocetin showed significant effects on coronary heart disease by inhibiting lipoprotein oxidation [33, 39], on neurodegenerative diseases [33, 39-44], on retinal function recovery by increasing retinal blood flow [33, 45], on reducing blood pressure and maintaining kidney function [46] and also used as anticonvulsive agent [33, 47]. Most notable discovery in relation to crocetin is to enhance oxygen diffusivity during shock and reperfusion that ultimately lead to increased ATP production [48, 49].

\section{CROCETIN AND CANCER}

Although there are many reports on the effects of saffron extract on cancer, there is very limited information available for crocetin effects on cancer. Saffron and its derivatives particularly crocetin have demonstrated significant anticancer activity in breast, lung, pancreatic and leukemic cells. Table 1 summarizes the effects of crocetin against several cancer types and also presents the underlying mechanisms of action. 


\section{Breast cancer}

Crocetin and its analogues separated from different Crocus species inhibited breast cancer cell proliferation [31]. MCF-7 and MDA-MB-231 breast cancer cells showed concentrationdependent inhibition of proliferation by crocetin and this effect was independent of estrogen receptor. This study also suggested that crocetin can be used as chemopreventive agent in breast cancer [31]. Crocetin also exerts proapoptotic effect in MCF-7 breast cancer cells indicating caspase dependent pathway through increased expression of Bax protein [50].

\section{Cervical cancer}

It has been reported that HeLa cells demonstrated significant reduction of colony formation and cellular RNA and DNA synthesis by crocetin like compounds from saffron [51]. Saffron was found to decrease the viability of HeLa cells [52]. In that study, crocetin showed dosedependent inhibition of DNA, RNA and protein synthesis (over the range of 1-200 $\mu \mathrm{g} / \mathrm{ml}$ ). Crocetin also suppressed DNA-dependent RNA polymerase II enzyme following inhibition of RNA synthesis [53]. Some of the similar derivatives of crocetin derived from saffron, such as crocin, safranal and picrocrocin, showed significant reduction of growth of $\mathrm{HeLa}$ cells and exhibited wide cytoplasmic vacuole-like areas, reduced cytoplasm, cell shrinkage and pyknotic nuclei suggesting apoptosis [54]. It has been also demonstrated using UVspectroscopy that crocetin interacts with tRNA internally with a binding constant $1.4 \pm 0.31$ $\mu \mathrm{M}$. This indicated the binding activity of crocetin at molecular level suggesting its cancer preventive effect [55].

\section{Colorectal cancer}

In another study, crocin (obtained from Crocus sativas) significantly inhibited the growth of colorectal cancer cells and it has been suggested as a viable agent for the treatment of colorectal cancer [56].

\section{Leukemia}

In two other studies using promyelocytic leukemia (HL60) and human myelogenous leukemia (K562) cells, crocetin demonstrated significant cytoxicity and inhibited proliferation with as low as $0.8 \mu \mathrm{M}$ concentrations $[8,57]$. Cytotoxicity of crocetin on various other leukemic cell lines (L1210 and P388) has also been reported [54, 57].

\section{Liver cancer}

The cytotoxicity and DNA-adduct formation of rat liver microsomes activated by aflatoxin B1 (AFB1) in the C3H10T1/2 fibroblast cells are significantly inhibited by pretreatment of crocetin [58]. Crocetin treatment resulted in a decrease in AFB1-DNA adduct formation in vitro that suggested the protective effect of crocetin on the AFB1-cytotoxity due to the elevation of cytosolic glutathione (GSH) following the activities of GSH-S-transferase (GST) formation as cellular defense mechanisms. Crocetin pretreatment in rats protected hepatic AFB1-induced hepatic damage and AFB1-DNA adducts formation due to the elevation hepatic GSH, activities of GST and glutathione peroxidase (GSH-Px) [59]. In another study, significant suppression of AFB1-induced hepatotoxic lesions was observed as indicated by reduction of activities of serum aspartate aminotransferase, alanine 
aminotransferase, alkaline phosphatase and gamma-glutamyl transpeptidase (GGT) by crocetin in rats [60]. Inhibitory effect of crocetin on benzo[a]pyrene-induced genotoxicity and neoplastic transformation in $\mathrm{C} 3 \mathrm{H} 1 \mathrm{OT} 1 / 2$ cells is due to a mechanism that increased the activity of GSH and reduced the formation of benzo[a]pyrene-DNA adducts [61]. Crocetin also inhibited the formation of malondialdehyde (MDA), a marker for lipid peroxidation, induced by reactive oxygen species (ROS) generated by the activity of xanthine oxidase (XO) in primary hepatocytes and protected against oxidative damage [62]. Therefore, these studies indicated that crocetin displayed protective action against the ROS due to direct scavenging that inhibited free radical production following neoplastic transformation [61, 62]. Saffron was also reported to decrease the viability of HepG2 cells [51].

\section{Lung cancer}

Another in vivo study reported that crocetin has antitumor activity in a lung cancer animal model by scavenging free radicals and increasing the activity of drug metabolizing enzymes [63]. Crocetin scavenged free radicals as evidenced by inhibiting lipid peroxidation and increase of the activity of GST, GSH-Px, catalase, and superoxide dismutase due to crocetin treatment. Crocetin also decreased marker enzymes such as arylhydrocarbon-hydroxylase (AHH), lactate dehydrogenase (LDH), GGT, adenosine deaminase (ADA) and 5'nucleotidase related to carcinogen following administration of benzo $[a]$ pyrene $(\mathrm{B}[a] \mathrm{P})$ in lung tissues [63]. Furthermore, Magesh et al. [64] also demonstrated that crocetin was capable of inhibiting proliferation of lung cancer cells as determined by PCNA, glycoproteins and polyamine synthesis. This study strongly suggested that the protective effect of crocetin on $\mathrm{B}[a] \mathrm{P}$-induced lung carcinogenesis in Swiss albino mice are likely due to the inhibitory effects on polyamine synthesis and glycoprotein alterations. Crocetin has shown inhibitory effects on intracellular nucleic acid synthesis and colony formation of A549 (lung carcinoma) and VA13 (SV-40 transformed fetal lung fibroblast) cells [51].

\section{Pancreatic cancer}

Our group has studied, for the first time, the anticancer potential of crocetin in pancreatic cancer by using various pancreatic cancer cells as well as a xenograft athymic mouse model [32]. In this study, crocetin inhibited the proliferation of Mia PaCa2, BxPC3, Capan-1 and ASCPC-1 cells. Crocetin significantly inhibited cell distribution in S-phase impairing DNA replication. This confirms the inhibition of DNA synthesis in crocetin-treated pancreatic cancer cells. The increase of accumulation of cells indicated G2/M arrest in Mia-PaCa-2 cells due to crocetin treatment. The cell cycle entry of cells depends upon the activity of several regulatory proteins including $\mathrm{Cdc}-2, \mathrm{Cdc}-25 \mathrm{c}$, cyclin B1 as well as other proteins. The expression of cyclin B1 was assessed and the inhibition of expression of cyclin B1 and inactivation of $\mathrm{Cdc} 2$ due to inhibition of Cdc-25c could be the major step for arrest in G2/M phase following crocetin treatment. Overall, these studies evaluating major cell cycle checkpoint proteins indicate crocetin is effective as antiproliferative agent in accomplishing cell cycle arrest. Crocetin significantly reduced epidermal growth factor receptor (EGFR) expression and phosphorylation as indicated by the ratio of phosphorylated and unphosphorylated EGFR proteins in MIA-PaCA-2 cells. Crocetin showed antitumorigenic effects on pancreatic cancer in an athymic (nude) mice model by regressing tumor growth following inhibition of proliferation as determined by PCNA and EGFR expression in 
crocetin-treated animals [32]. Immunohistochemical and Western blot analysis revealed a significant decrease of EGFR phosphorylation and expression in the tumors developed in nude mice after crocetin treatment. This indicated that crocetin is an effective inhibitor of EGFR activity that in turn impaired growth of pancreatic cancer. In this study, the ratio of $\mathrm{Bax} / \mathrm{Bcl}-2$ was significantly increased both $\mathrm{Mia} \mathrm{PaCa}-2$ cells and in pancreatic tumors after crocetin treatment, which suggested that the reduction on imbalance between antiapoptotic (Bcl-2) and proapoptotic (Bax) proteins could be a major factor for the antitumorigenic activity of crocetin [32]. It has been demonstrated recently that crocetin in combination with lower doses of paclitaxol or cisplatin inhibited proliferation and stimulated apoptosis in pancreatic cancer (unpublished observations). This study indicated that crocetin showed promising effect in combinational therapy with conventional chemotherapeutic agents.

At present, it is not known that whether the effect of crocetin on pancreatic cancer regression is receptor dependent or independent mechanisms, which is being investigated in our laboratory. Nevertheless, based on currently available data, it can be concluded that crocetin could be used as a novel therapy for pancreatic cancer due to significant antitumorigenic effect and thereby can be of great therapeutic benefit against this aggressive cancer.

\section{Skin cancer}

Administration of crocetin delayed the onset of skin tumor initiation and decreased its tumor formation initiated with dimethylbenz $[a]$ anthracene (DMBA) and promoted by croton oil in Swiss-Webster mice [65]. Similar antitumor activity of crocetin also observed in hairless mice with skin tumors developed by the application of DMBA and croton oil [13].

In summary, crocetin demonstrated significant inhibitory effect on the growth of a number of cancer cells. The tumor growth-suppressing effect of crocetin could be due to the reduction in the synthesis of DNA, RNA and protein by crocetin in tumor cells. It has also been demonstrated that crocetin inhibited RNA polymerase II activity in neoplastic cells [53]. Crocetin also interferes with histone H1 structure and H1-DNA interaction suggesting that epigenetic mechanisms could be implicated in the anticarcinogenic action of this natural product [66].

\section{CONCLUSIONS}

The exact mechanism of protective activity of crocetin is not clear at present but several hypotheses have been put forwarded which suggest that carotenoids can be converted to vitamin A, can enhance carcinogen metabolism, can act as antioxidant or inhibit nucleic acid synthesis [30, 32, 38]. Fig. (2) summarizes the possible mechanisms of action of crocetin. We propose that crocetin inhibits DNA synthesis and RNA polymerase II activity, that in turn, inhibits proliferation by impairing EGFR, phospho Cdc-2, Cdc25c, cyclin B1 and increases apoptosis by enhancing the ratio of $\mathrm{Bax} / \mathrm{Bcl}-2$ that ultimately inhibits tumor formation. Crocetin also inhibits oxidant injury due to lipid peroxidation and these antioxidant effects could be responsible for inhibition of tumor formation. All these studies warrant more research to evaluate the exact antitumor mechanism(s) of crocetin before embarking on clinical trials. Nevertheless, the emerging in vitro and in vivo studies on 
several types of cancers as presented in this review underscore the potential of crocetin in the prevention and treatment of human malignancies.

\section{ACKNOWLEDGMENTS}

This work was supported in-part by Midwest Biomedical Research Foundation, VISN 15 Established Investigator Award and Kansas University Cancer Center Pilot Project Award to AD.

\section{REFERENCES}

1. Jemal A, Siegel A, Xu J, Ward E. Cancer statistics. CA Cancer J. Clin. 2010 Epub ahead of print.

2. Lee BM, Park KK. Beneficial and adverse effects of chemopreventive agents. Mutat. Res. 2003; 523:265-278. [PubMed: 12628524]

3. Nair SC, Kurumboor SK, Hasegawa JH. Saffron chemoprevention in biology and medicine: a review. Cancer Biother. 1995; 10:257-264. [PubMed: 8590890]

4. Aggarwal BB, Shishodia S. Molecular targets of dietary agents for prevention and therapy of cancer. Biochem. Pharmacol. 2006; 71:1397-1421. [PubMed: 16563357]

5. Kunnumakkara, AB.; Anand, P.; Harikumar, KB.; Aggarwal, BB. DNA damage and cancer prevention by polyphenols: Chemoprevention of cancer and DNA damage by dietary factors. Knasmüller, S.; Demarini, DM.; Johnson, I.; Gerhauser, C., editors. Wiley-VCH; Weinheim: 2009. p. $455-482$.

6. Kim-Jun H. Inhibitory effects of alpha and beta carotene on croton oil-induced or enzymatic lipid peroxidation and hydrogen peroxide production in mouse epidermis. Int. J. Biochem. 1993; 25:911915. [PubMed: 8344446]

7. Colburn, N. A comprehensive survey. In: Slaga, TJ., editor. In carcinogenesis. Vol. 5. Raven Press; New York: 1979. p. 35-36.

8. Tarantilis PA, Morjani H, Pollissiou M, Manfeit M. Inhibition of growth and induction of differentiation of promyelocytic leukemia (HL-60) by caratenoids from Crocus sativus $L$. Anticancer Res. 1994; 14:1913-1918. [PubMed: 7847826]

9. Greasey, WA. Cancer: An Introduction. In: Greasey, WA., editor. Unproven and Dietary Treatments for Cancer. Oxford, Oxford University Press; New York: 1981. p. 230-237.

10. Fields AL, Soprano DR, Soprano KJ. Retenoids in biological control and cancer. J. Cell Biochem. 2007; 102:886-898. [PubMed: 17902161]

11. Brtko J. Retinoids, rexinoids and their cognate nuclear receptors: character and their role in chemoprevention of selected malignant diseases. Biomed. Pap. Med. Fac. Univ. Palacky Olomouc. Czech Repub. 2007; 151:187-194. [PubMed: 18345250]

12. Niles RM. Biomarker and animal models for assessment of retinoid efficacy in cancer chemoprevention. Acta. Pharmacol. Sin. 2007; 28:1383-1391. [PubMed: 17723172]

13. Mathews-Roth M. Antitumor activity of beta-carotene, canthaxanthin and phytoene. Oncology. 1982; 39:33-37. [PubMed: 6799883]

14. Lippman SM, Kessler JF, Meyskens FL Jr. Retinoids as preventive and therapeutic anticancer agents (Part I). Cancer Treat. Rep. 1987; 71:391-405. [PubMed: 3548957]

15. Lippman SM, Kessler JF, Meyskens FL Jr. Retinoids as preventive and therapeutic anticancer agents (Part II). Cancer Treat. Rep. 1987; 71:493-515. [PubMed: 3552220]

16. Wald N. Retinol, beta-carotene and cancer. Cancer Surveys. 1987; 6:635-651. [PubMed: 3330683]

17. Nastruzzi C, Simoni D, Manfredini S, Barbieri R, Feriotto G, Baraldi PG, Spandidos D, Guarneri M, Gambari R. New synthetic reinoids: effects on proliferation and differentiation. Anticancer Res. 1989; 9:1377-1384. [PubMed: 2589824]

18. Boone CW, Kelloff GJ, Malone WE. Identification of candidate cancer chemopreventive agents and their evaluation in animal models and human clinical trials: a review. Cancer Res. 1990; 50:29. [PubMed: 2403415] 
19. Fontana JA, Miranda D, Mezu AB. Retinoic acid inhibition of human breast carcinoma proliferation is accompanied by the synthesis of a Mr 39,000 protein. Cancer Res. 1990; 50:19771982. [PubMed: 2317786]

20. Bertram JS, Pung A, Churley M, Kappoch TJ, Wilkins IR, Cooney RV. Diverse carotenoids protect against chemical induced neoplastic transformation. Carcinogenesis. 1991; 12:671-678. [PubMed: 2013131]

21. Ranaldi G, Bellovino D, Palozza P, Gaetani S. Beneficial or detrimental effects of carotenoids contained in food: cell culture models. Mini Rev. Med. Chem. 2007; 7:1120-1128. [PubMed: 18045215]

22. Black HS, Mathews-Roth MM. Protective role of butylated hydroxytolune and certain carotenoids in photocarcinogenesis. Phytochem. Photobiol. 1991; 53:707-716.

23. Zieglar RG. A review of epidemiologic evidence that carotinoids reduced the risk of cancer. J. Nutr. 1989; 119:116-122. [PubMed: 2643694]

24. Kinlen LJ. Diet and breast cancer. Brit. Med. Bull. 1991; 47:462-469. [PubMed: 1933226]

25. Steinmetz KA, Potter JD, Folsom AR. Vegetables, fruit and lung cancer in Iowa women's health study. Cancer Res. 1993; 53:536-543. [PubMed: 8425185]

26. Nair SC, Panikkar KR. Antitumor principle from Ixora javanica. Cancer Lett. 1990; 49:121-126. [PubMed: 2306704]

27. Unnikrishnan MC, Kuttan R. Tumor reducing and anticarcinogenic activity of selected spices. Cancer Lett. 1990; 51:85-89. [PubMed: 2110862]

28. Nair SC, Pannikar B, Panikkar KR. Antitumor activity of saffron (Crocus sativus). Cancer Lett. 1991; 57:109-114. [PubMed: 2025883]

29. Bhat JV, Broker R. Riboflavine and thiamine contents of saffron Crocus Sativus. Nature. 1953; 172:544-545. [PubMed: 13099260]

30. Abdullaev FI, Espinosa-Aguirre JJ. Biomedical properties of saffron and its potential use of cancer therapy and chemopreventive trials. Cancer Detect. Prev. 2004; 28:426-432. [PubMed: 15582266]

31. Chryssanthi DG, Lamari FN, Iatrou G, Pylara A, Karamanos NK, Cordopatis P. Inhibition of breast cancer cell proliferation by style constituents of different Crocus species. Anticancer Res. 2007; 27:357-362. [PubMed: 17352254]

32. Dhar A, Mehta S, Dhar G, Dhar K, Banerjee S, Van Veldhuizen P, Campbell DR, Banerjee SK. Crocetin inhibits pancreatic cancer cell proliferation and tumor progression in a xenograft mice model. Mol. Cancer Ther. 2009; 8:315-323. [PubMed: 19208826]

33. Giaccio M. Crocetin from Saffron: An active component of an ancient spice. Clin. Rev. Food Sc. Nutr. 2004; 44:155-172.

34. Sujata V, Ravishankar GA, Venkataramn LV. Methods for the analysis of the saffron metabolites crocin, crocetins, picocrocin and safranal for the determination of the quality of the spice using thin layer chromatography, high performance liquid chromatography and gas chromatography. J. Chromatogr. 1992; 624:497-502.

35. Li N, Lin G, Kwan Y-W, Min Z-D. Simultaneous quantification of five major biologically active ingredients of saffron by high-performance liquid chromatography. J. Chromatogr. 1999; 849:349-355.

36. Abdullaev FI. Biological effects of saffron. Biofactors. 1993; 4:83-86. [PubMed: 8347278]

37. Alonso GL; Salinas MR, Esteban-Infantes FJ, Sanchez-Fernandez MA. Determination of safranal from saffron (Crocus sativus L.) by thermal desorption-gas chromatography. J Agric. Food Chem. 1996; 44:185-188.

38. Abdullaev FI. Cancer chemopreventive and tumoricidal properties of saffron (Crocus sativus L.). Exp. Biol. Med. 2002; 227:20-25.

39. Verma SK, Bordia A. Antioxidant property of saffron in man. Ind. J. Med. Sci. 1998; 52:205-207.

40. Abe K, Saito H. Effects of saffron extract and its constituent crocin on learning behavior and long term potentiation. Phytother. Res. 2000; 14:149-152. [PubMed: 10815004]

41. Abe K, Seguira M, Yamaguchi S, Shoyama Y, Saito H. Saffron extract prevents acetaldehydeinduced inhibition of long term potentiation in the rat dentate gyrus in vivo. Brain Res. 1999; 851:287-289. [PubMed: 10642859] 
42. Zhang Y, Shoyama Y, Sugiura M, Saito H. Effets of Crocus sativus L. on the ethanol-induced impairment of passive avoidance performances in mice. Biol. Pharm. Bull. 1994; 17:217-221. [PubMed: 8205119]

43. Sugura M, Shoyama Y, Saito H, Abe K. Crocin (crocetin di-gentiobiose ester) prevents the inhibitory effect of ethanol on long-term potentiation in the dentate gyrus in vivo. J. Pharmcol. Exp. Ther. 1994; 271:703-707.

44. Soeda S, Ochiai T, Paopong L, Tanaka H, Shoyama Y, Shimeno H. Crocetin suppresses tumor necrosis factor-alpha-induced cell death of neuronally differentiated PC-12 cells. Life Sci. 2001; 69:2887-2898. [PubMed: 11720092]

45. Xuan B, Zhou YH, Li N, Min ZD, Chiou GC. Effect of crocin analogs on ocular blood flow and retinal function. J. Ocul. Pharmacol. Ther. 1999; 15:143-152. [PubMed: 10229492]

46. Fatehi M, Rashidabady T, Fatehi-Hassanabad Z. Effects of Crocus sativus petals' extract on rat blood pressure and on response induced by electrical field stimulation in the rat isolated vas deferens and guinea-pig-ileum. J. Ethnopharmacol. 2003; 84:199-203. [PubMed: 12648816]

47. Hosseinzadeh H, Younesi HM. Antinociceptive and anti-inflammatory effects of Crocus sativus L. stigma and petal extracts in mice. BMC Pharmacol. 2002; 2:7-15. [PubMed: 11914135]

48. Giassi LJ, Poynter AK, Gainer JL. Trans sodium crocetinate for hemorrhagic shock: effect of time delay in initiating therapy. Shock. 2002; 18:585-588. [PubMed: 12462570]

49. Dhar A, Cherian G, Dhar G, Ray G, Sharma G, Banerjee SK. Molecular basis of protective effect of crocetin on survival and liver tissue damage following hemorrhagic shock. Mol. Cell Biochem. 2005; 278:139-146. [PubMed: 16180099]

50. Mousavi SH, Tavakkol-Afshari J, Brook A, Jafari-Anarkooli I. Role of capases and Bax protein in saffron-induced apoptosis in MCF-7 cells. Food Chem. Toxicol. 2009; 47:1909-1913. [PubMed: 19457443]

51. Abdullaev FI, Frenkel GD. Effect of saffron on cell colony formation and cellular nucleic acid and protein synthesis. Biofactors. 1992; 3:201-204. [PubMed: 1376126]

52. Tavakkol-Afshari J, Brook A, Mousavi SH. Study of cytotoxic and apoptogenic properties of saffron extract in human cancer cell lines. Food Chem. Toxicol. 2008; 46:3443-3447. [PubMed: 18790714]

53. Abdullaev FI. Inhibitory effect of crocetin on intracellular nucleic acid and protein synthesis in malignant cells. Toxicol. Lett. 1994; 70:243-251. [PubMed: 8296327]

54. Escribano J, Alonso GL, Coca-Prados M, Fernandez JA. Crocin, safranal and picrocrocin from saffron (Crocus sativus L) inhibit the growth of human cancer cells in vitro. Cancer Lett. 1996; 100:23-30. [PubMed: 8620447]

55. Kanakis CD, Tarantilis PA, Tajmir-Riahi HA, Polissiou MG. Interaction of tRNA with safranal, crocetin and dimethylcrocetin. J. Biomol. Struct. Dynam. 2007; 24:537-545.

56. Aung HH, Wang CZ, Ni M, Fishbein A, Mehendale SR, Xie JT, Shoyama CY, Yuan CS. Crocin from Crocus sativus possesses significant anti-proliferation effects on human colorectal cancer cells. Exp. Oncol. 2007; 29:175-180. [PubMed: 18004240]

57. Morjani H, Tarantilis P, Polissiou M, Manfeit M. Growth inhibition and induction of inhibition of erythroid differentiation activity by crocin, dimethyl-crocetine and $\beta$-carotene on K562 cells. Anticancer Res. 1990; 10:1398-1406.

58. Wang CJ, Shiah HS, Lin JK. Modulatory effect of crocetin on aflatoxin B1 cytotoxicity and DNA adduct formation in C3H10T1/2 fibroblast cell. Cancer Lett. 1991; 56:1-10. [PubMed: 1900736]

59. Wang CJ, Shiow SJ, Lin JK. Effects of crocetin on the hepatotoxicity and hepatic DNA binding of aflatoxin B1 in rats. Carcinogenesis. 1991; 12:459-462. [PubMed: 1672627]

60. Wang CJ, Hsu JD, Lin JK. Suppression of aflatoxin B1-induced lesions by crocetin (a natural carotenoid). Carcinogenesis. 1991; 12:1807-1810. [PubMed: 1934261]

61. Chang W-C, Lin Y-L, Lee M-J, Shiow S-J, Wang C-J. Inhibitory effect of crocetin on benzo(a)pyrene genotoxicity and neoplastic transformation in $\mathrm{C} 3 \mathrm{H} 10 \mathrm{~T} 1 / 2$ cells. Anticancer Res. 1996; 16:3603-3608. [PubMed: 9042228]

62. Tseng TH, Chu CY, Huang JM, Shiow SJ, Wang CJ. Crocetin protects against oxidative damage in rat primary hepatocytes. Cancer Lett. 1995; 97:61-67. [PubMed: 7585479] 
63. Magesh V, Singh JP, Selvendiran K, Ekambaram B, Sakthisekaran D. Antitumor activity of crocetin in accordance to tumor incidence, antioxidant status, drug metabolizing enzymes and histopathological studies. Mol. Cell. Biochem. 2006; 287:127-135. [PubMed: 16685462]

64. Magesh V, Durgabhavani K, Senthilnathan P, Rajendran P, Sakthisekaran D. In vivo protective effect of crocetin on benzo(a)pyrene induced lung cancer in swiss albino mice. Phytother. Res. 2009; 23:533-539. [PubMed: 19067387]

65. Gainer JL, Wallis DA, Jones JR. The effect of skin papilloma and rous sarcoma. Oncology. 1976; 33:222-224. [PubMed: 194195]

66. Ashrafi M, Bhataie SZ, Taghikhani M, Moosavi-Movahedi AA. The effect of carotenoids obtained from saffron on histone H1 structure and H1-DNA interaction. Int. J. Biol. Macromol. 2005; 36:246-252. [PubMed: 16087230] 


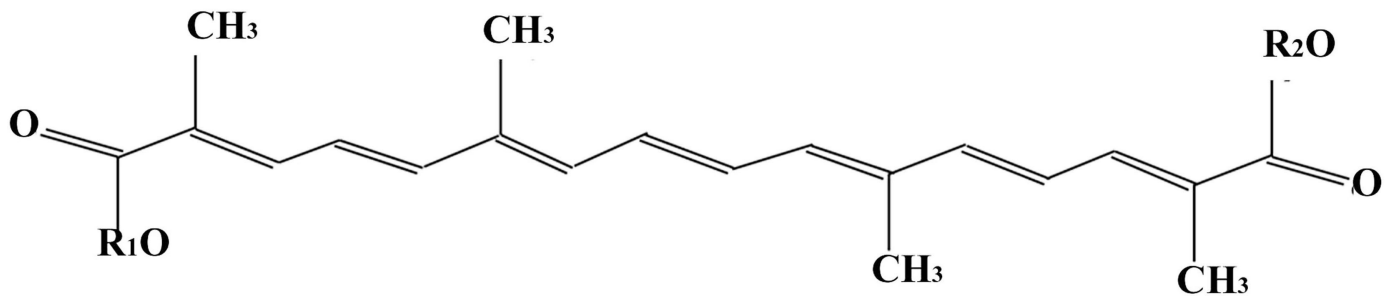

Fig. (1).

Chemical structures of crocetin. 


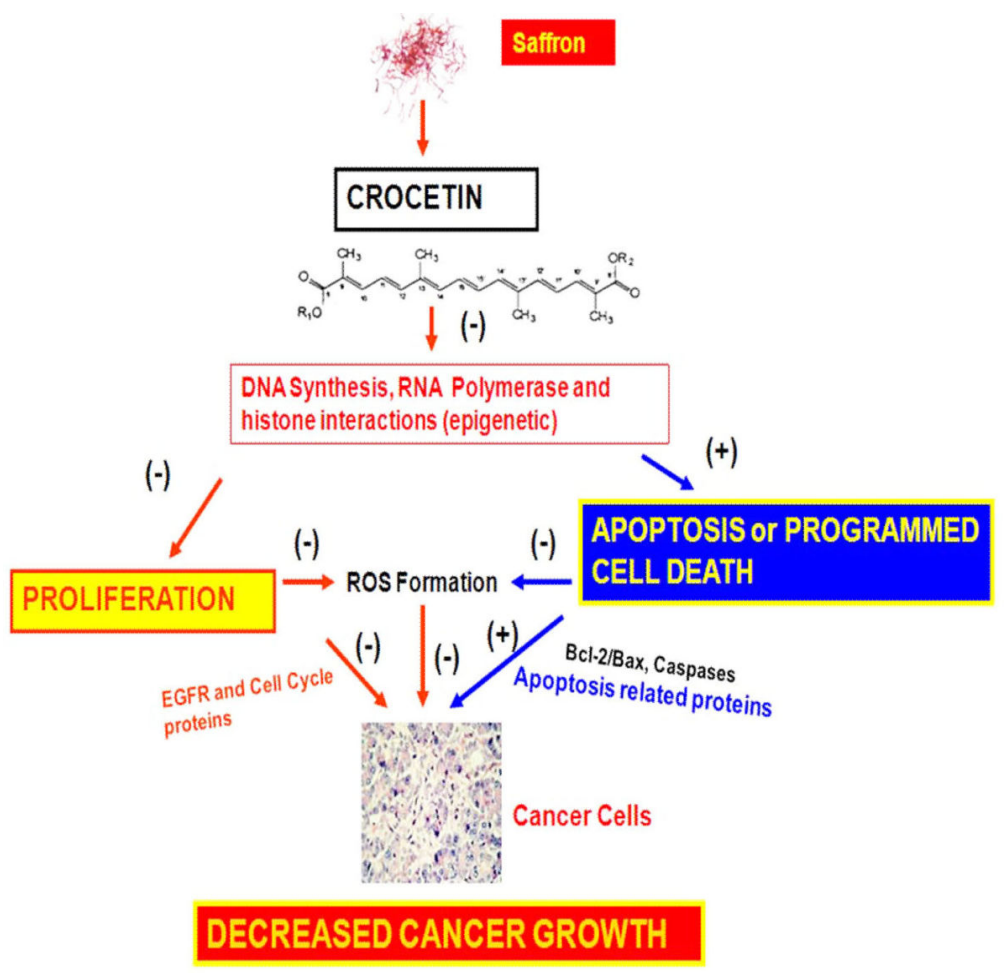

Fig. (2).

Possible chemopreventive mechanism of crocetin action on cancer. Simple model for possible action of crocetin in prevention of cancer as described through different signaling pathways. Possible regulation of growth and apoptosis pathways by crocetin were suggested by up-regulation (+) and down-regulation (-) in this figure. 
Table 1

In vitro and In vivo Effects of Crocetin against Several Cancers

\begin{tabular}{|c|c|c|c|}
\hline Types of Cancers & Cell lines/Animal models & Factors Affected & References \\
\hline \multirow[t]{2}{*}{ Breast Cancer } & MCF-7, MDA-MB-231 & $\downarrow$ Proliferation & Chryssanthi et al. [31] \\
\hline & MCF-7, MDA-MB-231 & $\uparrow$ Apoptosis & Mousavi et al. 2009 [50] \\
\hline \multirow[t]{5}{*}{ Cervical Cancer } & HeLa Cells & $\begin{array}{l}\downarrow D N A, \text { RNA and protein } \\
\text { synthesis }\end{array}$ & Abdullaev \& Frenkel [51] \\
\hline & HeLa Cells & $\uparrow$ Apoptosis & Tavakkol-Afshari et al. [52] \\
\hline & HeLa Cells & $\downarrow$ RNA polymerase activity & Abdullaev [53] \\
\hline & HeLa Cells & $\uparrow t R N A$ interaction & Kanakis et al. [55] \\
\hline & HeLa Cells & $\begin{array}{l}\downarrow \text { RNA, DNA and } \\
\text { protein synthesis }\end{array}$ & Escribano et al. [54] \\
\hline Colorectal Cancer & HCT-116, SW-480, and HT-29 & $\downarrow$ Proliferation & Aung et al. [56] \\
\hline \multirow[t]{3}{*}{ Leukemia } & HL60 & $\begin{array}{l}\downarrow \text { Cytotoxity and } \\
\text { proliferation }\end{array}$ & Tarantilis et al. [8] \\
\hline & L1210 and P388 & $\begin{array}{l}\downarrow \text { Cytotoxity and } \\
\text { proliferation }\end{array}$ & Morjani et al. [57] \\
\hline & K562 & $\begin{array}{l}\downarrow \text { Cytotoxity and } \\
\text { proliferation }\end{array}$ & Tarantilis et al. [8]; Morjani et al. [57] \\
\hline \multirow[t]{4}{*}{ Liver Cancer } & $\begin{array}{l}\text { Wistar rat (AFB1) } \\
\text { C3H1OT1/2 cells }\end{array}$ & $\downarrow$ Lipid perxidation & Wang et al. [58] \\
\hline & $\begin{array}{l}\text { Wistar rat (AFB1) } \\
\text { C3H1OT1/2 cells }\end{array}$ & $\downarrow$ Reactive oxygen species & Wang et al. [59] \\
\hline & $\begin{array}{l}\text { Wistar rat (AFB1) } \\
\text { C3H1OT1/2 cells }\end{array}$ & $\downarrow$ DNA-adduct formation & Chang et al. [61] \\
\hline & HepG2 & $\begin{array}{l}\downarrow \text { Proliferation, } \\
\uparrow \text { apoptosis }\end{array}$ & Tavakkol-Afshari et al. [52] \\
\hline \multirow[t]{4}{*}{ Lung Cancer } & Swiss albino mice $(\mathrm{B}[a] \mathrm{P})$ & $\begin{array}{l}\downarrow \text { Lipid peroxidation, } \\
\uparrow \mathrm{GST}, \\
\uparrow \text { catalases, } \\
\uparrow \text { superoxide dismutase }\end{array}$ & Magesh et al. [63] \\
\hline & Swiss albino mice $(\mathrm{B}[a] \mathrm{P})$ & $\downarrow$ polyamine & Magesh et al. [64] \\
\hline & A549 lung carcinoma & $\begin{array}{l}\downarrow \text { DNA, RNA and protein, } \\
\downarrow \text { RNA polymerase II }\end{array}$ & Abdullev 1994 [53] \\
\hline & VA-13 fetal lung fibroblast & $\begin{array}{l}\downarrow \text { DNA, RNA and protein, } \\
\downarrow \text { RNA Polymerase II }\end{array}$ & Abdullev 1994 [53] \\
\hline Pancreatic Cancer & $\begin{array}{l}\text { Mia PaCa2, BxPc3, } \\
\text { Capan-1 and ASPC-1 cells; } \\
\text { Athymic xenograft mice } \\
\text { (Mia PaCa-2) }\end{array}$ & $\begin{array}{l}\downarrow \text { Proliferation, } \\
\uparrow \text { Cdc2 phosphorylation, } \\
\downarrow \text { Cdc25c } \downarrow \downarrow \text { cyclin B1, } \\
\downarrow \text { EGFR phsophoryaltion, } \\
\uparrow \text { apoptosis, } \uparrow \text { Bax, } \downarrow \text { Bcl- } 2, \\
\downarrow \text { Tumor formation }\end{array}$ & Dhar et al. [32] \\
\hline Skin Cancer & $\begin{array}{l}\text { Swiss Webster mice } \\
\text { (DMBA and croton oil) }\end{array}$ & $\downarrow$ Tumor formation & $\begin{array}{l}\text { Gainer } \text { et al. [65]; } \\
\text { Mathews-Roth [13] }\end{array}$ \\
\hline
\end{tabular}

